Vol. XXI, No. 1

\title{
The Dry Prairies
}

\section{by Keith F. Best, Swift Current}

In our present series, we have moved from the dunelands through the sandhills to the dry hillsides. Now let us look at some of the plants found in the drier portions of the open prairie and on the eroded areas. As much of this area is only used by the rancher, we might first study two plants of some economic importance to livestock men.

Winter-fat (Eurotia lanata), often called White Sage, Winter Sage or Feather Sage, is not a true sage, but belongs to the Goosefoot family. The generic name Eurotia is from the Greek euros (mold) referring to the white hairy herbage. The specific name lanata, from the Latin lana (wool or hair), also alludes to the dense, woolly hairs that cover the plant.

Winter-fat is a perennial half-shrub or herb from six to 18 inches in

height. It has fine, star-like, white hairs which becomes rusty as the plant matures. The leaves are narrow, one-half to two inches long, and have rolled margins. Male and female flowers are borne separately on the same plant, with the male clusters above. The female flowers and frui are enclosed in two bracts and have two horns at the top. The entire female inflorescence is covered witl long, white, silky hairs making the plant very conspicuous in the fall.

Widely distributed over the $d r$ prairie and on heavy lands, it ex tends to Texas and is commonly th dominant and most conspicuous plan on vasi areas of winter range. I grows in distinct patches from sev eral feet to thousands of acres i area, and with its deep tap root an numerous extensive lateral roots remarkably resistant to drough

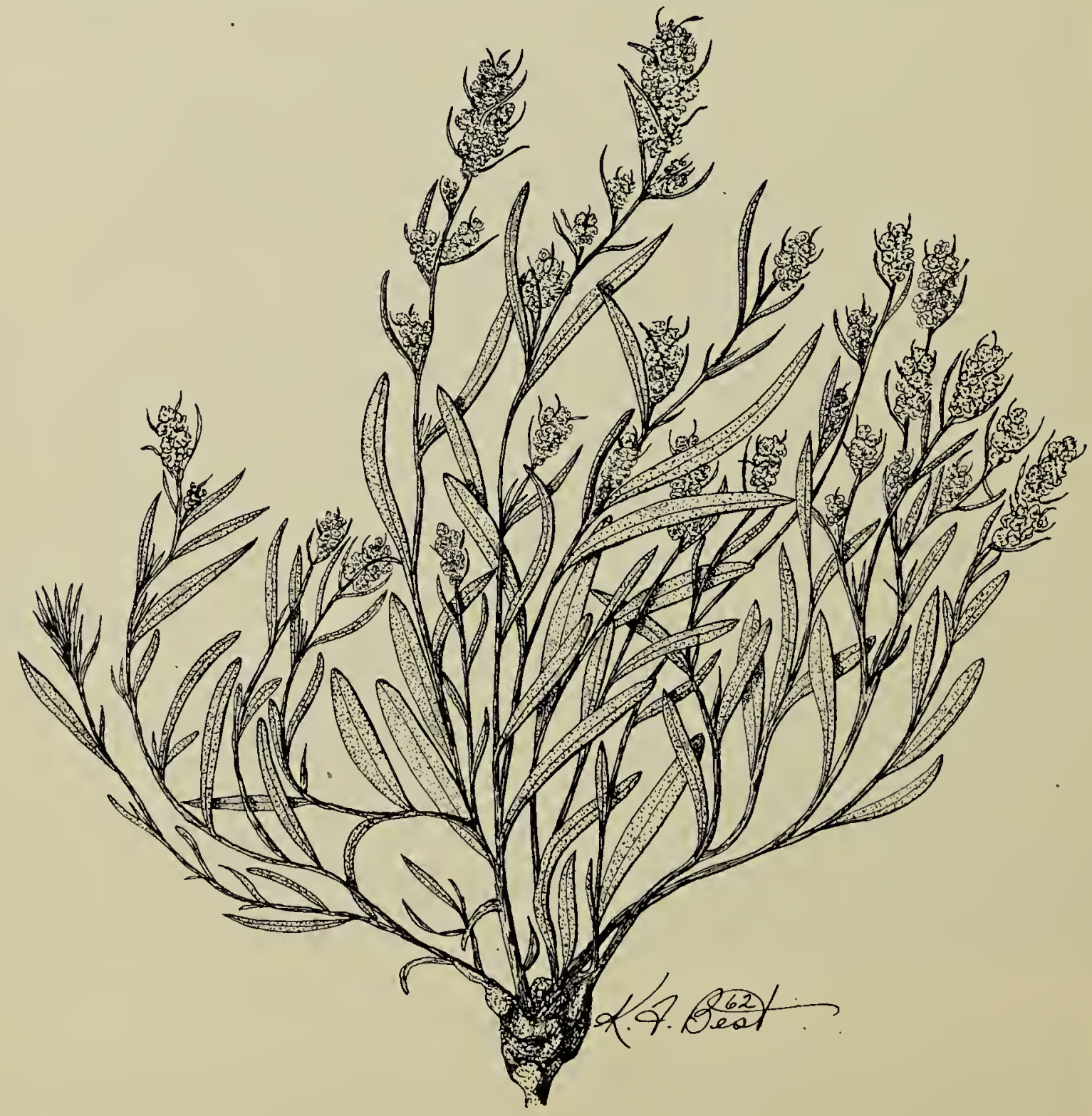

Fig. 1. Winter-fat 


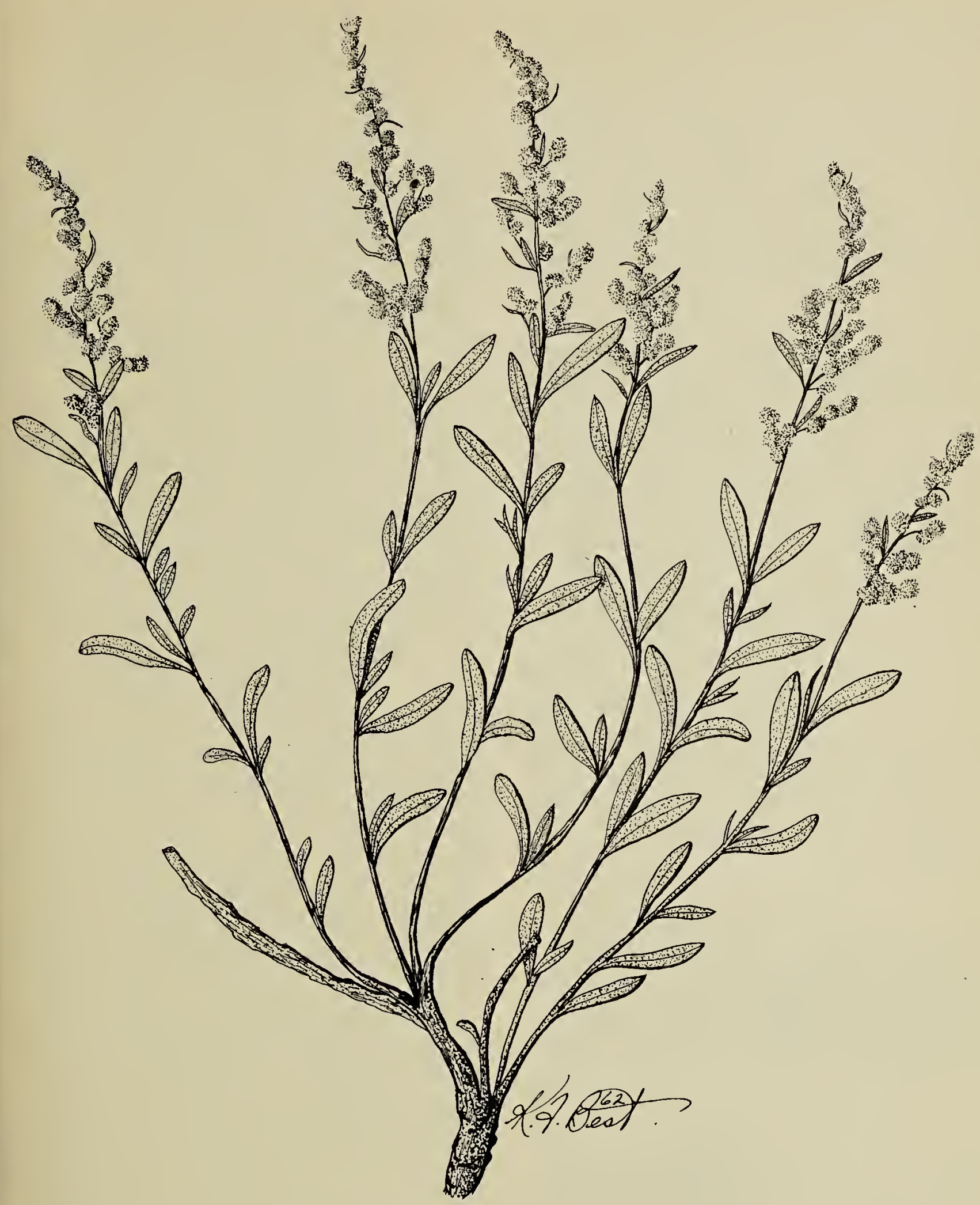

Fig. 2. Nuttall's Atriplex

Grazed by all classes of livestock, it $s$ very high in crude protein. Stock rrazed on lands where Winter-fat srows thrive well and are said to pe remarkably free of disease beause of the tonic properties of this lant. It is a prolific seeder and is asily grown under cultivation, espeially if the seed is covered by raking $r$ harrowing. Although it grows well inder conditions of controlled grazng, it may be completely destroyed y overgrazing and is often replaced y Rabbitbrush.

Nuttall's Atriplex .(Atriplex nutallii) is one of the saltbush species in the Goosefoot family, and is found on badlands, eroded soils and alkali flats throughout the southwest. It is a low, leafy shrub, with a very deep rooting system. Generally growing almost prostrate, it may branch up to $21 / 2$ feet in height. The stem and leaves are pale green, with a fine scurfiness. Leaves are $3 / 4$ to two inches long, from linear-oblong to spatulate or ovate. Male and female flowers are on separate plants. Few plants are more alkali tolerant than this species and it is readily eaten by livestock, being highly rated for its mineral content and palatability. 